\title{
The Depiction of Medical Errors in a Sample of Medical Television Shows
} \author{
Molly Carney ${ }^{1}$, Tonya S. King ${ }^{2}$, Anna Yumen ${ }^{3}$, Carissa Harnish-Cruz ${ }^{3}$, Renyta Scales ${ }^{3}$, Robert P. Olympia
}

1. Pediatrics, Penn State College of Medicine, Hershey, USA 2. Public Health Sciences, Penn State College of Medicine, Hershey, USA 3. Emergency Medicine, Penn State College of Medicine, Hershey, USA 4. Pediatric Emergency Medicine, Penn State College of Medicine, Hershey, USA

Corresponding author: Molly Carney, mcarney@pennstatehealth.psu.edu

\begin{abstract}
Background: Medical errors and adverse events may affect up to $7.5 \%$ of hospitalizations, although observational studies suggest the numbers could be even higher. Previous studies have shown that medical television (TV) shows may be a major driver when it comes to a patient's medical knowledge and perspectives.
\end{abstract}

Methods: Six episodes from the first season of eight medical TV series were analyzed by four reviewers. Demographics of the healthcare provider responsible for the error, demographics of the victim, type of error, setting of error, level of disability, and reporting of the error were recorded. Data was compared with event rates from US hospitals.

Results: A total of 242 medical errors (average 6.4/hr) were included in the analysis. The healthcare provider responsible for the error was often an attending physician (55.8\%), while victims were often White (73.6\%), males (55.0\%), aged 16-44 years (50.8\%). Errors in diagnosis (28.9\%) and operative errors (19.4\%) were most common. Compared with data from US hospitals, TV series depicted more errors in diagnosis $(\mathrm{p}<0.001)$ and fewer operative errors $(p<0.001)$. The most common levels of disability following medical errors were emotional trauma (37.6\%) and temporary injury (30.2\%). Emotional trauma was significantly overrepresented and temporary injuries were underrepresented $(\mathrm{p}<0.001)$. Error was not reported to the victim in $49.2 \%$ of events.

Conclusion: There were multiple discrepancies between errors depicted on TV and US hospital data. This may lead to viewer fear and anxiety that results in delays in seeking medical care and increased medicolegal cases. Healthcare systems should attempt to reduce the incidence of medical errors and adverse events by ensuring competencies of their providers, instituting methods of risk analysis and prevention, and training providers on methods of proper error disclosure.

Review began 10/12/2020 Review ended 11/20/2020 Published 12/09/2020

(c) Copyright 2020 Carney et al. This is an open access article distributed under the terms of the Creative Commons Attribution License CC-BY 4.0., which permits unrestricted use, distribution, and reproduction in any medium, provided the original author and source are credited.
Categories: Internal Medicine, Medical Education, Quality Improvement

Keywords: medical error, adverse events, healthcare quality, medical education, continuing education

\section{Introduction}

Medical errors are responsible for up to 251,000 deaths in the United States each year, making it the third leading cause of death [1]. In addition to mortality, medical errors and negligence can lead to disability, delays in recovery or emotional trauma [2]. Data from US hospitals shows that adverse events occur in $3.2 \%$ $7.5 \%$ of hospitalizations, with the most common errors being operative (44.9\%-49.3\%) or drug-related (15.7\%-19.3\%) errors that result in temporary injury (16.5\%-73.8\%) or insignificant injury (10.8\%-56.8\%) [36]. However, observational studies have shown even higher rates of medical error [7]. Observers of a surgical unit in a Chicago teaching hospital found that up to $45.8 \%$ of patients experienced an event associated with an inappropriate decision. Of the 1,047 patients studied, $17.7 \%$ experienced a serious event but only $1.2 \%$ filed a claim, evidencing how even serious medical errors can go unreported [8].

Although this data speaks to the prevalence of medical error occurring in the US healthcare system, many healthcare consumers may be unaware of these statistics until it personally affects them. With the increasing popularity of medical television (TV) shows, viewers often get a dramatized look into the world of medicine. Cultivation theory argues that repeated exposure to events or ideas in the media can influence people's beliefs about the real world [9]. For example, several studies have found that the general population lists TV as a primary source of information and education about resuscitation [10]. Unfortunately, medical TV shows are known to over-exaggerate medical and traumatic scenarios to capture the interest of their audience. Several studies examining medical TV shows have shown that the survival rates associated with cardiopulmonary resuscitation (CPR) events are often inaccurate, and favor improved short-term and longterm survival rates when compared with reports for in-hospital CPR [10-13]. Another example of overexaggeration in medical TV shows is in the depiction of major disasters. In one study describing major 
disasters depicted in ED-associated medical TV shows, the authors demonstrated an average mortality rate $0.14 \%$ higher than the weighted mortality rate of 10 major US disasters [14].

To our knowledge, there have been no published studies examining the depiction of medical errors depicted in US medical TV shows. The objective of this study was to characterize the depiction of medical errors in a sample of eight medical TV shows and compare these characterizations with the US hospital data.

\section{Materials And Methods}

\section{Data collection}

Eight medical TV series released during 1994-2018 were selected for this study (Table 1). In order to represent medical TV series over several decades, four series released before 2005 (ER, Scrubs, House and Grey's Anatomy) and four series released after 2005 (The Resident, The Good Doctor, Code Black and Chicago Med) were selected. Series were selected based on high ratings and viewership at the time of release, as well as diversity of medical settings and genres (Table 1). Since each series had a different number of episodes during Season 1, the first and last three episodes of the first season of each series were independently reviewed by four medical student reviewers.

\begin{tabular}{|c|c|c|c|c|c|}
\hline $\begin{array}{l}\text { Medical } \\
\text { Series } \\
\text { Name }\end{array}$ & Network & Genre & $\begin{array}{l}\text { Date } \\
\text { Premiered }\end{array}$ & $\begin{array}{l}\text { Episodes } \\
\text { in } \\
\text { Season } 1\end{array}$ & Description \\
\hline $\begin{array}{l}\text { The } \\
\text { Resident }\end{array}$ & Fox & Drama & Jan 2018 & 14 & $\begin{array}{l}\text { Focuses on the lives and duties of surgery, internal medicine and administrative staff } \\
\text { in an Atlanta hospital with a specific interest in the bureaucratic practices of a } \\
\text { hospital }\end{array}$ \\
\hline $\begin{array}{l}\text { The Good } \\
\text { Doctor }\end{array}$ & $A B C$ & Drama & Sept 2017 & 18 & $\begin{array}{l}\text { Highlights the trials and tribulations of a young autistic, savant surgical resident at a } \\
\text { fictional San Jose hospital }\end{array}$ \\
\hline $\begin{array}{l}\text { Code } \\
\text { Black }\end{array}$ & CBS & Drama & Sept 2015 & 18 & $\begin{array}{l}\text { Centered on four first-year residents and their colleagues who work in an } \\
\text { overcrowded, understaffed and poorly funded ED in Los Angeles }\end{array}$ \\
\hline $\begin{array}{l}\text { Chicago } \\
\text { Med }\end{array}$ & NBC & Drama & Nov 2015 & 18 & $\begin{array}{l}\text { Set in an urban ED, the show highlights how characters from a number of different } \\
\text { training levels and specialties work together to provide state-of-the-art care }\end{array}$ \\
\hline $\begin{array}{l}\text { Grey’s } \\
\text { Anatomy }\end{array}$ & $A B C$ & Drama & $\begin{array}{l}\text { March } \\
2005\end{array}$ & 9 & $\begin{array}{l}\text { Follows the life of first-year surgical residents at a Seattle hospital as they struggle } \\
\text { to balance a demanding residency schedule with drama in their personal lives }\end{array}$ \\
\hline House & Fox & Drama & Nov 2004 & 22 & $\begin{array}{l}\text { Centered on a drug-addicted attending physician who often clashes with team } \\
\text { members and hospital administration as he flouts rules and procedure to solve } \\
\text { mystery ailments }\end{array}$ \\
\hline Scrubs & $\begin{array}{l}\text { (later on } \\
\mathrm{ABC})\end{array}$ & Comedy & Oct 2001 & 24 & $\begin{array}{l}\text { Told through the eyes of a first-year internal medicine resident, the series focuses on } \\
\text { both the drama and humor of life as a first-year resident }\end{array}$ \\
\hline ER & NBC & Drama & Sept 1994 & 25 & $\begin{array}{l}\text { Follows the lives, loves and losses of staff at a Chicago ED as they care for critically } \\
\text { ill patients }\end{array}$ \\
\hline
\end{tabular}

TABLE 1: Description of medical TV series

The following data was recorded for each medical error: (1) role, race and gender of up to two healthcare providers responsible for the medical error; (2) race, gender and age of the victim of the medical error; (3) type of medical error; (4) disability experienced by the victim; (5) setting where the error occurred and (6) reporting of the medical error to the victim and subsequent action. Race and ethnicity were combined into one category referred to as "race" and categories were based on those laid forth by the US Census (White, Black or African American, Asian, American Indian or Alaskan Native, Native Hawaiian or other Pacific Islander and Hispanic) [15]. Age ranges for the victims of medical error were based on ranges (0-15, 16-44, 45-64, >65 years) used in the Harvard Medical Practice Study (henceforth, Harvard study) [3,4]. Types of medical error (operative, anesthesia, medical procedure, child birth, drug-related, improper diagnosis, improper therapy, falls and other) were based on categories used in both the Harvard study and Thomas et al.'s [5] study of medical centers in Utah and Colorado (henceforth, Utah/Colorado study) (Table 2). These represent two of the largest medical error studies conducted in the United States [3-5]. 


\section{Cureus}

\begin{tabular}{|c|c|}
\hline Type of Error & Description \\
\hline Operative & $\begin{array}{l}\text { Issues arising up to two weeks after a surgical procedure that are the direct result of improper decision making by the surgical } \\
\text { team }\end{array}$ \\
\hline Anesthesia & Errors occurring during the administration, maintenance or withdrawal of both local and systemic anesthesia \\
\hline $\begin{array}{l}\text { Medical } \\
\text { procedure }\end{array}$ & Errors occurring during a procedure done by a non-surgical team member in some location other than an operating room \\
\hline Child birth & Errors related to labor, delivery or the post-partum period that result in harm to the mother or child \\
\hline Drug related & Errors in administering the wrong type or dosage of medication; also includes improper prescription of controlled substances \\
\hline $\begin{array}{l}\text { Improper } \\
\text { diagnosis }\end{array}$ & $\begin{array}{l}\text { Patient was either given the incorrect diagnosis or there is a prolonged delay in determining the diagnosis that causes distress } \\
\text { or additional impairment }\end{array}$ \\
\hline $\begin{array}{l}\text { Improper } \\
\text { therapy }\end{array}$ & $\begin{array}{l}\text { Patient is either given the wrong treatment or there is a prolonged delay in providing treatment, despite the proper diagnosis } \\
\text { being concluded }\end{array}$ \\
\hline Falls & Patient falls while under the supervision of hospital staff \\
\hline Other & All other errors that do not properly fit into the described categories \\
\hline
\end{tabular}

\section{TABLE 2: Types of medical errors}

Categories and descriptions are based on the Harvard Medical Practice Study and Thomas et al.'s study of medical centers in Utah and Colorado.

Disability ratings for the victim (emotional trauma, insignificant injury, temporary injury, permanent minor/major and death) were also similar to those used in the Harvard and Utah/Colorado studies and were defined by the National Association of Insurance Commissioners (Table 3) [2-5]. These error and disability descriptions were provided to all reviewers to ensure reviewer consistency. Definitions were kept simple so that reviewer opinions could mirror those of the general public viewing these series. When the medical error resulted in physical injury, the type of injury was recorded using the following categories: laceration, bruise, rash, infection, fracture, burns, blood/fluid loss, loss of body part/organ, brain damage, thrombotic event, cardiac arrhythmia, seizure or other. The setting where the medical error occurred was categorized into inpatient care unit, emergency department, operating room (OR), labor and delivery, outpatient clinic, pharmacy, laboratory or other. Reporting of the medical error was categorized as error not reported to the victim, error reported without legal action taken or error reported with legal action taken. Reporting of the medical error needed to be performed before the end of the episode to be included in the analysis.
Disability
Category
Description
Emotional trauma
The patient experiences an unnecessary, unpleasant emotion such as fear, sadness, etc., despite there being no physical harm
Insignificant injury Lacerations, contusions, minor scars, rash, etc., where no delay in recovery occurs
Temporary injury Infection, drug side effect, fracture set improperly, patient falls, etc., where recovery is complete but delayed
Permanent minor Irreversible loss of fingers, loss or damage to organs, etc., where the injury is not disabling
Permanent major Irreversible paraplegia, blindness, deafness, loss of limbs, brain damage, etc., which results in permanent disability
Death
Patient dies as a direct result of the medical error

\section{TABLE 3: Descriptions of disability categories}

Categories and descriptions are based on those provided by the National Association of Insurance Commissioners.

\section{Statistical analysis}

For each area of interest (demographics, error type, disability, etc.) the percentage of each category was calculated for each series, as well as the summation of all eight TV series. 
The average rate per hour was estimated using repeated measures Poisson regression for overall medical error, victim race, victim gender, type of medical error, setting of error and resultant disability, with adjustment for reviewer. This approach takes into account the varying duration of each show, along with the correlation among the multiple reviewers evaluating each series. Results were reported in terms of modelestimated average event rates per hour, 95\% confidence intervals and p-values. The level of agreement among the four reviewers was assessed by evaluating the extended Kappa coefficient for measuring agreement among multiple raters, and reported with 95\% confidence interval. Significance was defined as $\mathrm{p}<0.05$.

Lastly, these findings were compared to real-life event rates from studies of US hospitals $[3-5,8]$. For areas where comparative studies utilized different categories, a qualitative comparison was given. For areas where studies with similar categories were present, a two-sided test of binomial proportions was used to assess statistical significance versus the US hospital proportion. If two studies were available for comparison, the average of these two studies was used. For setting of error and level of disability, our categories did not match perfectly with categories used in outside studies; therefore, adjustments were made. For setting, the category "inpatient room" included patient's room and the ICU; the category “operating room" included OR, catherization lab and procedure rooms; the category “outpatient” included physician's office, ambulatory care unit and day surgery, the category "other" included radiology and nursing homes. For disability, the temporary minor and temporary major categories were combined into one category of temporary injury.

\section{Results}

\section{Rate of medical error}

The average rate of medical errors depicted in our sample of medical TV shows was 6.4 events per hour (95\% CI 5.18-7.97). The rate of medical errors was significantly different among the eight series, ranging from 2.3/hr in ER to 9.5/hr in Code Black (p<0.001). Series released before 2005 had a rate of 7.20/hr (95\% CI 6.348.06) whereas series released after 2005 had 5.54/hr (95\% CI 4.33-6.75), which was not significantly different $(\mathrm{p}=0.35)$. There was a significant difference among reviewers in the average number of errors reported per hour ( $\mathrm{p}<0.001$ ), ranging from $2.5 / \mathrm{hr}$ to $14.8 / \mathrm{hr}$. This variation was accounted for in all further statistical models. The extended Kappa coefficient was 0.20 (95\% CI 0.08-0.32), indicating only low-moderate agreement among the four reviewers.

\section{Demographics for the healthcare provider responsible for medical error}

A White (75.6\%), male (69.0\%), attending physician (55.8\%) was the most common provider responsible for an error (Table 4). Of note, "others", which included physicians' assistants, nurse practitioners, nurses, and other hospital staff, composed only $5.8 \%$ of the healthcare providers depicted as responsible. Additionally, despite several of the TV series in our sample focusing on an incoming intern class, Grey's Anatomy and Scrubs were the only series that depicted interns as responsible for the majority of medical errors $(70.0 \%$ and $80.0 \%$, respectively). Although some studies categorize the healthcare provider responsible for the medical error by specialty of provider, no data from US hospitals addresses the role, race and gender for these providers. 


\section{Cureus}

\begin{tabular}{|c|c|c|c|c|c|c|c|c|c|c|c|c|c|c|}
\hline \multirow[b]{2}{*}{ Series } & \multirow[b]{2}{*}{ Errors } & \multicolumn{5}{|l|}{ Role } & \multicolumn{5}{|l|}{ Race } & \multicolumn{3}{|l|}{ Gender } \\
\hline & & Attending & Fellow & Resident & Intern & Other ${ }^{\mathrm{a}}$ & White & Black & Asian & Hispanic & Other ${ }^{b}$ & Male & Female & $N / A^{b}$ \\
\hline \multirow{2}{*}{$\begin{array}{l}\text { The } \\
\text { Resident }\end{array}$} & \multirow{2}{*}{41} & 29 & 0 & 8 & 4 & 4 & 33 & 8 & 4 & 0 & 0 & 28 & 17 & 0 \\
\hline & & $(70.7 \%)^{\star}$ & $(0.0 \%)$ & (19.5\%) & (9.8\%) & (9.8\%) & $(80.5 \%)^{\star}$ & (19.5\%) & (9.8\%) & $(0.0 \%)$ & $(0.0 \%)$ & $(68.3 \%)^{\star}$ & $(41.5 \%)$ & $(0.0 \%)$ \\
\hline \multirow{2}{*}{$\begin{array}{l}\text { The } \\
\text { Good } \\
\text { Doctor }\end{array}$} & \multirow{2}{*}{23} & 10 & 0 & 7 & 7 & 2 & 15 & 6 & 1 & 4 & 0 & 20 & 6 & 0 \\
\hline & & $(43.5 \%)^{\star}$ & $(0.0 \%)$ & $(30.4 \%)$ & $(30.4 \%)$ & (8.7\%) & $(65.2 \%)^{\star}$ & (26.1\%) & (4.3\%) & (17.4\%) & $(0.0 \%)$ & $(87.0 \%)^{\star}$ & (26.1\%) & $(0.0 \%)$ \\
\hline \multirow{2}{*}{$\begin{array}{l}\text { Code } \\
\text { Black }\end{array}$} & \multirow{2}{*}{50} & 26 & 9 & 3 & 18 & 0 & 35 & 14 & 7 & 0 & 0 & 35 & 21 & 0 \\
\hline & & $(52.0 \%)^{\star}$ & (18.0\%) & $(6.0 \%)$ & (36.0\%) & $(0.0 \%)$ & $(70.0 \%)^{\star}$ & (28.0\%) & (14.0\%) & $(0.0 \%)$ & $(0.0 \%)$ & $(70.0 \%)^{\star}$ & $(42.0 \%)$ & $(0.0 \%)$ \\
\hline \multirow{2}{*}{$\begin{array}{l}\text { Chicago } \\
\text { Med }\end{array}$} & \multirow{2}{*}{31} & 17 & 8 & 5 & 1 & 0 & 25 & 2 & 4 & 0 & 0 & 15 & 16 & 0 \\
\hline & & $(54.8 \%)^{\star}$ & (25.8\%) & (16.1\%) & (3.2\%) & $(0.0 \%)$ & $(80.6 \%)^{*}$ & (6.5\%) & (12.9\%) & $(0.0 \%)$ & $(0.0 \%)$ & (48.4\%) & $(51.6 \%)^{\star}$ & $(0.0 \%)$ \\
\hline \multirow{2}{*}{$\begin{array}{l}\text { Grey's } \\
\text { Anatomy }\end{array}$} & \multirow{2}{*}{30} & 8 & 2 & 0 & 21 & 2 & 24 & 2 & 5 & 2 & 0 & 20 & 13 & 0 \\
\hline & & $(26.7 \%)$ & $(6.7 \%)$ & $(0.0 \%)$ & $(70.0 \%)^{\star}$ & $(6.7 \%)$ & $(80.0 \%)^{\star}$ & $(6.7 \%)$ & $(16.7 \%)$ & $(6.7 \%)$ & $(0.0 \%)$ & $(66.7 \%)^{\star}$ & (43.3\%) & $(0.0 \%)$ \\
\hline \multirow{2}{*}{ Hous } & \multirow{2}{*}{41} & 37 & 12 & 0 & 0 & 4 & 34 & 11 & 0 & 0 & 8 & 31 & 14 & 8 \\
\hline & & $(90.2 \%)^{*}$ & (29.3\%) & $(0.0 \%)$ & $(0.0 \%)$ & (9.8\%) & $(82.9 \%)^{\star}$ & (26.8\%) & $(0.0 \%)$ & $(0.0 \%)$ & (19.5\%) & $(75.6 \%)^{\star}$ & (34.1\%) & (19.5\%) \\
\hline \multirow{2}{*}{ Scrubs } & \multirow{2}{*}{15} & 3 & 0 & 0 & 12 & 0 & 8 & 5 & 2 & 0 & 0 & 11 & 4 & 0 \\
\hline & & (20.0\%) & $(0.0 \%)$ & $(0.0 \%)$ & $(80.0 \%)^{*}$ & $(0.0 \%)$ & $(53.3 \%)^{*}$ & (33.3\%) & (13.3\%) & $(0.0 \%)$ & $(0.0 \%)$ & $(73.3 \%)^{\star}$ & (26.7\%) & $(0.0 \%)$ \\
\hline \multirow{2}{*}{ ER } & \multirow{2}{*}{11} & 5 & 0 & 4 & 0 & 2 & 9 & 0 & 0 & 0 & 2 & 7 & 2 & 2 \\
\hline & & $(45.5 \%)^{*}$ & $(0.0 \%)$ & (36.4\%) & $(0.0 \%)$ & (18.2\%) & $(81.8 \%)^{\star}$ & $(0.0 \%)$ & $(0.0 \%)$ & $(0.0 \%)$ & (18.2\%) & $(63.6 \%)^{\star}$ & (18.2\%) & (18.2\%) \\
\hline \multirow{2}{*}{ Overall $^{\mathrm{C}}$} & \multirow{2}{*}{242} & 135 & 31 & 27 & 63 & 14 & 183 & 48 & 23 & 6 & 10 & 167 & 93 & 10 \\
\hline & & $(55.8 \%)^{\star}$ & (12.8\%) & (11.2\%) & $(26.0 \%)$ & (5.8\%) & $(75.6 \%)^{\star}$ & (19.8\%) & (9.5\%) & (2.5\%) & (4.1\%) & $(69.0 \%)^{\star}$ & (38.4\%) & (4.1\%) \\
\hline
\end{tabular}

TABLE 4: Demographic information for the healthcare provider responsible for the error including role, race and gender

'Includes physicians' assistants, nurse practitioners, nurses, aids and other hospital staff.

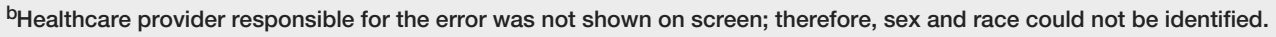

'Percentages add up to $>100 \%$ in a given category because some errors had more than one person responsible for the error.

*Denotes the most common healthcare provider responsible for the error, race and gender for each series, as well as overall.

\section{Demographics for the victim of medical error}

The most common depicted victim was a White (73.6\%) male (55.0\%) between the ages of 16 and 44 (50.8\%) (Table 5). Although the rate of medical error was significantly different among the victim's race ranging from $0.7 / \mathrm{hr}$ for Hispanic to $5.0 / \mathrm{hr}$ for White ( $\mathrm{p}<0.001$ ), there was no significant difference among gender categories $(2.7 / \mathrm{hr}$ for females, $3.9 / \mathrm{hr}$ for males, and $2.1 / \mathrm{hr}$ for unknown, $\mathrm{p}=0.19)$. 


\begin{tabular}{|c|c|c|c|c|c|c|c|c|c|c|c|c|c|c|c|}
\hline \multirow[b]{2}{*}{ Series } & \multirow[b]{2}{*}{ Errors } & \multicolumn{5}{|l|}{ Race } & \multicolumn{3}{|l|}{ Gender } & \multicolumn{5}{|c|}{ Age (Years) } & \multirow{2}{*}{$\begin{array}{l}\text { Average } \\
\text { Age }\end{array}$} \\
\hline & & White & Black & Asian & Hispanic & $N / A^{a}$ & Male & Female & $N / A^{a}$ & $0-15$ & $16-44$ & $45-64$ & $>65$ & $N / A^{a}$ & \\
\hline \multirow{2}{*}{$\begin{array}{l}\text { The } \\
\text { Resident }\end{array}$} & \multirow{2}{*}{41} & 31 & 2 & 0 & 3 & 5 & 24 & 13 & 4 & 1 & 21 & 15 & 0 & 4 & \multirow{2}{*}{36.6} \\
\hline & & $(75.6 \%)^{*}$ & $(4.9 \%)$ & $(0.0 \%)$ & (7.3\%) & (12.2\%) & $(58.5 \%)^{*}$ & (31.7\%) & $(9.8 \%)$ & $(2.4 \%)$ & $(51.2 \%)^{*}$ & (36.6\%) & $(0.0 \%)$ & $(9.8 \%)$ & \\
\hline \multirow{2}{*}{$\begin{array}{l}\text { The } \\
\text { Good } \\
\text { Doctor }\end{array}$} & \multirow{2}{*}{23} & 22 & 1 & 0 & 0 & 0 & 14 & 9 & 0 & 7 & 12 & 4 & 0 & 0 & \multirow{2}{*}{26.3} \\
\hline & & $(95.7 \%)^{*}$ & $(4.3 \%)$ & $(0.0 \%)$ & $(0.0 \%)$ & $(0.0 \%)$ & $(60.9 \%)^{*}$ & (39.1\%) & $(0.0 \%)$ & (30.4\%) & $(52.2 \%)^{*}$ & (17.4\%) & $(0.0 \%)$ & $(0.0 \%)$ & \\
\hline \multirow{2}{*}{$\begin{array}{l}\text { Code } \\
\text { Black }\end{array}$} & \multirow{2}{*}{50} & 24 & 23 & 0 & 3 & 0 & 20 & 29 & 1 & 4 & 27 & 17 & 1 & 1 & \multirow{2}{*}{38.4} \\
\hline & & $(48.0 \%)^{*}$ & $(48.0 \%)$ & $(0.0 \%)$ & $(6.0 \%)$ & $(0.0 \%)$ & $(40.0 \%)$ & $(58.0 \%)^{*}$ & $(2.0 \%)$ & $(8.0 \%)$ & $(54.0 \%)^{*}$ & (34.0\%) & $(2.0 \%)$ & $(2.0 \%)$ & \\
\hline \multirow{2}{*}{$\begin{array}{l}\text { Chicago } \\
\text { Med }\end{array}$} & \multirow{2}{*}{31} & 20 & 11 & 0 & 0 & 0 & 13 & 18 & 0 & 3 & 19 & 5 & 4 & 0 & \multirow{2}{*}{39.4} \\
\hline & & $(64.5 \%)^{*}$ & (35.5\%) & $(0.0 \%)$ & $(0.0 \%)$ & $(0.0 \%)$ & (41.9\%) & $(58.1 \%)^{*}$ & $(0.0 \%)$ & $(9.7 \%)$ & $(61.3 \%)^{*}$ & (16.1\%) & (12.9\%) & $(0.0 \%)$ & \\
\hline \multirow{2}{*}{$\begin{array}{l}\text { Grey's } \\
\text { Anatomy }\end{array}$} & \multirow{2}{*}{30} & 25 & 2 & 0 & 0 & 3 & 15 & 13 & 2 & 10 & 7 & 5 & 4 & 4 & \multirow{2}{*}{30.3} \\
\hline & & $(83.3 \%)^{*}$ & $(6.7 \%)$ & $(0.0 \%)$ & $(0.0 \%)$ & $(10.0 \%)$ & $(50.0 \%)^{*}$ & $(43.3 \%)$ & $(6.7 \%)$ & $(33.3 \%)^{*}$ & (23.3\%) & $(16.7 \%)$ & (13.3\%) & $(13.3 \%)$ & \\
\hline \multirow{2}{*}{ House } & \multirow{2}{*}{41} & 37 & 0 & 4 & 0 & 0 & 31 & 10 & 0 & 0 & 33 & 8 & 0 & 0 & \multirow{2}{*}{29.3} \\
\hline & & $(90.2 \%)^{*}$ & $(0.0 \%)$ & $(9.8 \%)$ & $(0.0 \%)$ & $(0.0 \%)$ & $(75.6 \%)^{*}$ & $(24.4 \%)$ & $(0.0 \%)$ & $(0.0 \%)$ & $(80.5 \%)^{*}$ & $(19.5 \%)$ & $(0.0 \%)$ & $(0.0 \%)$ & \\
\hline \multirow{2}{*}{ Scrubs } & \multirow{2}{*}{15} & 12 & 0 & 0 & 0 & 3 & 9 & 6 & 0 & 0 & 4 & 8 & 0 & 3 & \multirow{2}{*}{46.7} \\
\hline & & $(80.0 \%)^{*}$ & $(0.0 \%)$ & $(0.0 \%)$ & $(0.0 \%)$ & (20.0\%) & $(60.0 \%)^{*}$ & $(40.0 \%)$ & $(0.0 \%)$ & $(0.0 \%)$ & $(26.7 \%)$ & $(53.3 \%)^{*}$ & $(0.0 \%)$ & $(20.0 \%)$ & \\
\hline \multirow{2}{*}{ ER } & \multirow{2}{*}{11} & 7 & 2 & 0 & 0 & 2 & 7 & 4 & 0 & 2 & 0 & 4 & 3 & 2 & \multirow{2}{*}{53.8} \\
\hline & & $(63.6 \%)^{*}$ & (18.2\%) & $(0.0 \%)$ & $(0.0 \%)$ & (18.2\%) & $(63.6 \%)^{*}$ & (36.4\%) & $(0.0 \%)$ & (18.2\%) & $(0.0 \%)$ & $(36.4 \%)^{*}$ & (27.3\%) & (18.2\%) & \\
\hline \multirow{2}{*}{ Overall } & & 178 & 41 & 4 & 6 & 13 & 133 & 102 & 7 & 27 & 123 & 66 & 12 & 14 & \\
\hline & & $(73.6 \%)^{*}$ & (16.9\%) & $(1.7 \%)$ & $(2.5 \%)$ & (5.4\%) & $(55.0 \%)^{*}$ & (42.1\%) & $(2.9 \%)$ & (11.2\%) & $(50.8 \%)^{*}$ & (27.3\%) & $(5.0 \%)$ & $(5.8 \%)$ & \\
\hline
\end{tabular}

\section{TABLE 5: Demographic Information for the victim of medical error including race, gender and age}

apatient could not be seen enough to determine the race, gender or approximate age (e.g., covered by drapes and then not discussed outside of that event).

*Denotes the most common victim race, gender and age for each series, as well as overall.

Our findings are consistent with an observational study that found that White males were the most common victims of medical error. However, whereas our data reported $74 \%$ of the victims were White, that observational study reported more diversity of victims with $46 \%$ White and $43 \%$ Black [8]. Code Black and Chicago Med, both focusing on urban EDs, were the only series to represent a close split between White and Black victims.

In terms of age, our data is inconsistent with US hospital data. Whereas the Harvard Study found that the majority of victims $(40.6 \%$ ) were $>65$ years of age, our data shows that only $5.8 \%$ of medical errors occurred in victims $>65$ years old [3]. Additionally, victims $>65$ years of age are only represented in four of the eight series.

\section{Type of medical error}

The most common types of medical error depicted were improper diagnosis (28.9\%), operative error (19.4\%) and drug-related error (12.0\%) (Table 6 ). The rate of medical errors by type was significantly different ( $<<0.001$ ), ranging from $1.1 / \mathrm{hr}$ for improper therapy to $2.7 / \mathrm{hr}$ for improper diagnosis. Series that focused on surgical residents, such as The Good Doctor and Grey's Anatomy, had higher rates of improper diagnosis (48.0\% and $29.0 \%$, respectively) than surgical error (20.0\% and $16.1 \%$, respectively), whereas, ED-based series, such as Code Black and Chicago Med, had higher rates of operative error (38.0\% and 38.7\%, respectively) than improper diagnosis (14.0\% and 6.5\%, respectively). 


\begin{tabular}{|c|c|c|c|c|c|c|c|c|c|c|}
\hline Series & Errors & Operative & Anesthesia & $\begin{array}{l}\text { Medical } \\
\text { Procedure }\end{array}$ & $\begin{array}{l}\text { Child } \\
\text { Birth }\end{array}$ & $\begin{array}{l}\text { Drug } \\
\text { Related }\end{array}$ & $\begin{array}{l}\text { Improper } \\
\text { Diagnosis }\end{array}$ & $\begin{array}{l}\text { Improper } \\
\text { Therapy }\end{array}$ & Falls & Other ${ }^{\mathrm{a}}$ \\
\hline \multirow{2}{*}{ The Resident } & \multirow{2}{*}{41} & 3 & 3 & 3 & 0 & 7 & 10 & 8 & 0 & 11 \\
\hline & & (7.3\%) & (7.3\%) & (7.3\%) & $(0.0 \%)$ & (17.1\%) & (24.4\%) & (19.5\%) & $(0.0 \%)$ & $(26.8 \%)^{*}$ \\
\hline \multirow{2}{*}{$\begin{array}{l}\text { The Good } \\
\text { Doctor }\end{array}$} & \multirow{2}{*}{23} & 5 & 0 & 2 & 0 & 2 & 12 & 3 & 0 & 1 \\
\hline & & (21.7\%) & $(0.0 \%)$ & (8.7\%) & $(0.0 \%)$ & (8.7\%) & $(52.2 \%)^{*}$ & (13.0\%) & $(0.0 \%)$ & $(4.3 \%)$ \\
\hline \multirow{2}{*}{ Code Black } & \multirow{2}{*}{50} & 19 & 7 & 6 & 4 & 3 & 7 & 3 & 0 & 1 \\
\hline & & $(38.0 \%)^{*}$ & (14.0\%) & $(12.0 \%)$ & (8.0\%) & (6.0\%) & (14.0\%) & $(6.0 \%)$ & $(0.0 \%)$ & $(2.0 \%)$ \\
\hline \multirow{2}{*}{ Chicago Med } & \multirow{2}{*}{31} & 12 & 5 & 5 & 3 & 0 & 2 & 0 & 0 & 4 \\
\hline & & $(38.7 \%)^{*}$ & (16.1\%) & (16.1\%) & $(9.7 \%)$ & $(0.0 \%)$ & $(6.5 \%)^{\star}$ & $(0.0 \%)$ & $(0.0 \%)$ & $(12.9 \%)$ \\
\hline \multirow{2}{*}{$\begin{array}{l}\text { Grey's } \\
\text { Anatomy }\end{array}$} & \multirow{2}{*}{30} & 5 & 4 & 2 & 0 & 2 & 9 & 4 & 0 & 5 \\
\hline & & (16.7\%) & (13.3\%) & $(6.7 \%)$ & $(0.0 \%)$ & $(6.7 \%)$ & $(30.0 \%)^{*}$ & $(13.3 \%)$ & $(0.0 \%)$ & $(16.7 \%)$ \\
\hline \multirow{2}{*}{ House } & \multirow{2}{*}{41} & 0 & 0 & 4 & 0 & 13 & 19 & 5 & 0 & 2 \\
\hline & & $(0.0 \%)$ & $(0.0 \%)$ & $(9.8 \%)$ & $(0.0 \%)$ & $(31.7 \%)$ & $(46.3 \%)^{*}$ & (12.2\%) & $(0.0 \%)$ & $(4.9 \%)$ \\
\hline \multirow{2}{*}{ Scrubs } & \multirow{2}{*}{15} & 3 & 0 & 4 & 0 & 2 & 3 & 1 & 0 & 2 \\
\hline & & (20.0\%) & $(0.0 \%)$ & $(26.7 \%)^{*}$ & $(0.0 \%)$ & (13.3\%) & $(20.0 \%)$ & $(6.7 \%)$ & $(0.0 \%)$ & $(13.3 \%)$ \\
\hline \multirow{2}{*}{ ER } & \multirow{2}{*}{11} & 0 & 0 & 0 & 0 & 0 & 8 & 3 & 0 & 0 \\
\hline & & $(0.0 \%)$ & $(0.0 \%)$ & $(0.0 \%)$ & $(0.0 \%)$ & $(0.0 \%)$ & $(72.7 \%)^{\star}$ & $(27.3 \%)$ & $(0.0 \%)$ & $(0.0 \%)$ \\
\hline \multirow{2}{*}{ Overall ${ }^{b}$} & \multirow{2}{*}{242} & 47 & 19 & 26 & 7 & 29 & 70 & 27 & 0 & 26 \\
\hline & & $(19.4 \%)^{\Phi}$ & $(7.9 \%)^{\Phi}$ & $(10.7 \%)$ & $(2.9 \%)$ & $(12.0 \%)^{\Phi}$ & $(28.9 \%)^{*}, \Phi$ & $(11.2 \%)^{\Phi}$ & $(0.0 \%)$ & $(10.7 \%)^{\Phi}$ \\
\hline $\begin{array}{l}\text { US hospital } \\
\text { data }\end{array}$ & & $48.9 \%$ & $1.2 \%$ & $10.6 \%$ & $2.6 \%$ & $17.5 \%$ & $6.9 \%$ & $4.8 \%$ & $1.5 \%$ & $5.83 \%$ \\
\hline Rate per hour & & 2.6 & 1.8 & 1.2 & 1.5 & 1.9 & 2.7 & 1.1 & 0.0 & 1.9 \\
\hline
\end{tabular}

\section{TABLE 6: Types of errors represented in medical TV series}

Errors are expressed as percentage of total errors and compared with statistics from the Harvard and Utah/Colorado studies. Rate per hour is also provided.

alncludes unauthorized procedures/treatment/tests, administrative errors, falsifying labs/results and practicing under the influence of drugs/alcohol.

bercentages may add up to $>100 \%$ because some errors fit into more than one category.

*Denotes most common type of error in each series, as well as overall.

${ }^{\Phi}$ Represents values that are significantly different from values reported in the Harvard and Utah studies.

Our findings are inconsistent with US hospital data where operative errors are the most common medical error $[4,5]$. Of note, improper diagnosis was significantly more common in our sample compared with US hospital statistics $(28.9 \%$ vs. $6.9 \%$, respectively, $\mathrm{p}<0.001)$ and operative error was significantly less common ( $19.4 \%$ vs. $48.8 \%$, respectively, $p<0.001)[4,5]$. Other types of errors that varied significantly between TV and US hospital statistics are denoted by phi $\left(^{\Phi}\right)$ in Table 6 .

\section{Setting where the error occurred}

The most common settings where errors occurred were on inpatient care units (34.7\%) and the ED (31.4\%) (Table 7$)$. The rate of errors per setting was significantly different $(\mathrm{p}<0.001)$, with the highest rate occurring in inpatient care units $(3.6 / \mathrm{hr})$ and the lowest rate occurring in outpatient clinics $(1.2 / \mathrm{hr})$. In general, where 
the majority of errors occurred varied with the main setting of each series. The only exception to this trend is The Good Doctor, which focuses on surgical residents but had the majority of errors occur in the ED (39.1\%).

\begin{tabular}{|c|c|c|c|c|c|c|c|c|c|}
\hline Series & Errors & $\begin{array}{l}\text { Inpatient Care } \\
\text { Unit }\end{array}$ & $\begin{array}{l}\text { Emergency } \\
\text { Department }\end{array}$ & $\begin{array}{l}\text { Operating } \\
\text { Room }\end{array}$ & $\begin{array}{l}\text { Labor \& } \\
\text { Delivery }\end{array}$ & $\begin{array}{l}\text { Outpatient } \\
\text { Clinic }\end{array}$ & Pharmacy & Lab & Other ${ }^{a}$ \\
\hline \multirow{2}{*}{ The Resident } & \multirow{2}{*}{41} & 11 & 6 & 10 & 0 & 8 & 0 & 4 & 2 \\
\hline & & $(26.8 \%)^{\star}$ & (14.6\%) & (24.4\%) & $(0.0 \%)$ & (19.5\%) & $(0.0 \%)$ & (9.8\%) & $(4.9 \%)$ \\
\hline \multirow{2}{*}{$\begin{array}{l}\text { The Good } \\
\text { Doctor }\end{array}$} & \multirow{2}{*}{23} & 5 & 9 & 6 & 0 & 0 & 0 & 0 & 3 \\
\hline & & (21.7\%) & $(39.1 \%)^{\star}$ & (26.1\%) & $(0.0 \%)$ & $(0.0 \%)$ & $(0.0 \%)$ & $(0.0 \%)$ & (13.0\%) \\
\hline \multirow{2}{*}{ Code Black } & \multirow{2}{*}{50} & 21 & 21 & 4 & 0 & 1 & 0 & 0 & 3 \\
\hline & & (42.0\%) & $(42.0 \%)^{*}$ & $(8.0 \%)$ & $(0.0 \%)$ & $(2.0 \%)$ & $(0.0 \%)$ & $(0.0 \%)$ & $(6.0 \%)$ \\
\hline \multirow{2}{*}{ Chicago Med } & \multirow{2}{*}{31} & 6 & 21 & 3 & 0 & 0 & 0 & 0 & 1 \\
\hline & & (19.4\%) & $(67.7 \%)^{\star}$ & (9.7\%) & $(0.0 \%)$ & $(0.0 \%)$ & $(0.0 \%)$ & $(0.0 \%)$ & (3.2\%) \\
\hline \multirow{2}{*}{$\begin{array}{l}\text { Grey's } \\
\text { Anatomy }\end{array}$} & \multirow{2}{*}{30} & 8 & 6 & 11 & 0 & 0 & 0 & 2 & 3 \\
\hline & & (26.7\%) & $(20.0 \%)$ & $(36.7 \%)^{\star}$ & $(0.0 \%)$ & $(0.0 \%)$ & $(0.0 \%)$ & $(6.7 \%)$ & $(10.0 \%)$ \\
\hline \multirow{2}{*}{ House } & \multirow{2}{*}{41} & 23 & 6 & 0 & 0 & 5 & 3 & 0 & 4 \\
\hline & & $(56.1 \%)^{\star}$ & (14.6\%) & $(0.0 \%)$ & $(0.0 \%)$ & (12.2\%) & $(7.3 \%)$ & $(0.0 \%)$ & $(9.8 \%)$ \\
\hline \multirow{2}{*}{ Scrubs } & \multirow{2}{*}{15} & 10 & 0 & 4 & 0 & 0 & 0 & 1 & 0 \\
\hline & & $(66.7 \%)^{\star}$ & $(0.0 \%)$ & $(26.7 \%)$ & $(0.0 \%)$ & $(0.0 \%)$ & $(0.0 \%)$ & $(6.7 \%)$ & $(0.0 \%)$ \\
\hline \multirow{2}{*}{ ER } & \multirow{2}{*}{11} & 0 & 7 & 0 & 0 & 2 & 0 & 0 & 2 \\
\hline & & $(0.0 \%)$ & $(63.6 \%)^{\star}$ & $(0.0 \%)$ & $(0.0 \%)$ & (18.2\%) & $(0.0 \%)$ & $(0.0 \%)$ & (18.2\%) \\
\hline \multirow{2}{*}{ Overall } & \multirow{2}{*}{242} & 84 & 76 & 38 & 0 & 16 & 3 & 7 & 18 \\
\hline & & $(34.7 \%)^{\star}, \Phi$ & $(31.4 \%)^{\Phi}$ & $(15.7 \%)^{\Phi}$ & $(0.0 \%)$ & $(6.6 \%)$ & $(1.2 \%)$ & $(2.9 \%)$ & (7.4\%) \\
\hline data & & $25.2 \%$ & $3.14 \%$ & $47.8 \%$ & $6.1 \%$ & $8.8 \%$ & N/A & N/A & $8.7 \%$ \\
\hline Rate per hour & & 3.6 & 2.7 & 1.9 & 0.0 & 1.2 & 1.42 & & 0.7 \\
\hline
\end{tabular}

\section{TABLE 7: Setting where the error occurred in medical TV series}

Data is expressed as percentage of total errors and compared with statistics from the Harvard and Utah/Colorado studies. Rate per hour is also provided.

ancludes ambulances, site of an emergency, radiology, nursing homes or unknown locations.

*Denotes the most common location for each series, as well as overall.

${ }^{\Phi}$ Represents values that are significantly different from values reported in the Harvard and Utah studies.

Our findings differ from US hospital data, where the majority of errors occur in the OR $[4,5]$. TV shows in our sample had significantly more errors occur in the ED (31.4\% vs. $3.14 \%$, respectively, $\mathrm{p}<0.001)$ and care unit (34.7\% vs. $25.3 \%$, respectively, $\mathrm{p}<0.001)$ and significantly fewer errors occur in the OR $(15.7 \%$ vs $47.9 \%$, respectively, $\mathrm{p}<0.001$ ) when compared to US hospital data $[4,5]$. It could not be determined if there was a significant difference between errors that occurred in the pharmacy and laboratory because these settings were not included in outside studies.

\section{Level of disability for the victim}

The most common levels of disability were emotional trauma (37.6\%) and temporary injuries (30.2\%) (Table 8 ). The rate of disability type varied significantly $(\mathrm{p}<0.001)$, ranging from $0.9 / \mathrm{hr}$ for permanent disability to 
3.6/hr for emotional trauma. The most common types of bodily injury were cardiac arrest/arrhythmia (22.3\%), blood loss (11.4\%) and infection (7.4\%). In general, more severe levels of disability, such as permanent disabilities and death, were not highly represented. Of note, The Resident was the only series with a high number of medical errors resulting in victim death $(26.8 \%)$.

\begin{tabular}{|c|c|c|c|c|c|c|c|c|}
\hline Series & Errors & $\begin{array}{l}\text { Emotional } \\
\text { trauma }\end{array}$ & $\begin{array}{l}\text { Insignificant } \\
\text { injury }\end{array}$ & $\begin{array}{l}\text { Temporary } \\
\text { Injury }\end{array}$ & $\begin{array}{l}\text { Permanent } \\
\text { minor }\end{array}$ & $\begin{array}{l}\text { Permanent } \\
\text { major }\end{array}$ & Death & Unknown ${ }^{a}$ \\
\hline \multirow{2}{*}{ The Resident } & \multirow{2}{*}{41} & 14 & 4 & 7 & 3 & 2 & 11 & 0 \\
\hline & & $(34.1 \%)^{*}$ & (9.8\%) & (17.1\%) & (7.3\%) & $(4.9 \%)$ & (26.8\%) & $(0.0 \%)$ \\
\hline \multirow{2}{*}{$\begin{array}{l}\text { The Good } \\
\text { Doctor }\end{array}$} & \multirow{2}{*}{23} & 10 & 2 & 9 & 0 & 0 & 1 & 1 \\
\hline & & $(43.5 \%)^{\star}$ & $(8.7 \%)$ & $(39.1 \%)$ & $(0.0 \%)$ & $(0.0 \%)$ & $(4.3 \%)$ & $(4.3 \%)$ \\
\hline \multirow{2}{*}{ Code Black } & \multirow{2}{*}{50} & 15 & 15 & 19 & 1 & 0 & 0 & 0 \\
\hline & & $(30.0 \%)^{*}$ & $(30.0 \%)^{*}$ & $(38.0 \%)$ & $(2.0 \%)$ & $(0.0 \%)$ & $(0.0 \%)$ & $(0.0 \%)$ \\
\hline \multirow{2}{*}{ Chicago Med } & \multirow{2}{*}{31} & 19 & 6 & 4 & 0 & 1 & 1 & 0 \\
\hline & & $(61.3 \%)^{*}$ & $(19.4 \%)$ & $(12.9 \%)$ & $(0.0 \%)$ & $(3.2 \%)$ & $(3.2 \%)$ & $(0.0 \%)$ \\
\hline \multirow{2}{*}{ Grey's Anatomy } & \multirow{2}{*}{30} & 7 & 9 & 4 & 2 & 1 & 3 & 4 \\
\hline & & (23.3\%) & $(30.0 \%)^{*}$ & (13.3\%) & $(6.7 \%)$ & (3.3\%) & (10.0\%) & (13.3\%) \\
\hline \multirow{2}{*}{ House } & \multirow{2}{*}{41} & 16 & 4 & 19 & 0 & 2 & 0 & 0 \\
\hline & & $(39.0 \%)^{\star}$ & $(9.8 \%)$ & $(46.3 \%)$ & $(0.0 \%)$ & $(4.9 \%)$ & $(0.0 \%)$ & $(0.0 \%)$ \\
\hline \multirow{2}{*}{ Scrubs } & \multirow{2}{*}{15} & 8 & 0 & 6 & 0 & 0 & 1 & 0 \\
\hline & & $(53.3 \%)^{*}$ & $(0.0 \%)$ & $(40.0 \%)$ & $(0.0 \%)$ & $(0.0 \%)$ & $(6.7 \%)$ & $(0.0 \%)$ \\
\hline \multirow{2}{*}{ ER } & \multirow{2}{*}{11} & 2 & 0 & 5 & 0 & 0 & 2 & 2 \\
\hline & & $(18.2 \%)$ & $(0.0 \%)$ & $(45.4 \%)^{\star}$ & $(0.0 \%)$ & $(0.0 \%)$ & $(0.0 \%)$ & $(0.0 \%)$ \\
\hline \multirow{2}{*}{ Overall } & \multirow{2}{*}{242} & 91 & 40 & 73 & 6 & 6 & 19 & 7 \\
\hline & & $(37.6 \%)^{*}$, & $(16.5 \%)^{\Phi}$ & $(30.2 \%)^{\Phi}$ & $(2.5 \%)$ & $(2.5 \%)$ & $(7.9 \%)$ & $(2.9 \%)$ \\
\hline $\begin{array}{l}\text { US hospital } \\
\text { data }\end{array}$ & & N/A & $33.8 \%$ & $45.1 \%$ & $4.5 \%$ & $2.9 \%$ & $10.1 \%$ & $3.3 \%$ \\
\hline Rate per hour & & 3.6 & 2.1 & 2.3 & 0.93 & & 1.7 & 1.6 \\
\hline
\end{tabular}

\section{TABLE 8: Level of victim disability represented in medical TV series}

Data is expressed as percentage of total errors and compared with statistics from the Harvard and Utah/Colorado studies. Rate per hour is also provided.

apatient outcome after the error is not discussed.

*Denotes the most common level of disability for each series, as well as overall.

${ }^{\Phi}$ Represents values that are significantly different from values reported in the Harvard and Utah studies.

Our findings differ from US hospital data. The Harvard study found the majority (56.8\%) of medical errors result in insignificant injury, and the Utah/Colorado study found the majority (73.8\%) of medical errors result in a temporary minor disability $[3,5]$. TV series showed fewer errors that resulted in insignificant injuries ( 16.5 vs. $33.8 \%$, respectively, $\mathrm{p}<0.001)$ and temporary injuries ( $30.2 \%$ vs. $45.2 \%$, respectively, $\mathrm{p}<0.001)[3,5]$. Although exact numbers were unavailable, $<1 \%$ of errors were estimated to result in only emotional injury whereas it represented $37.6 \%$ of errors in our sample [5].

\section{Medical error reporting}




\section{Cureus}

The majority of medical errors depicted in our sample were not reported to the victim (49.2\%), and only $3.7 \%$ of errors resulted in legal action (Table 9). The only series that depicted the majority of medical errors being reported to the victim were The Good Doctor and House. Additionally, only The Resident, The Good Doctor and ER depicted any legal action being taken against the provider responsible for the medical error.

\begin{tabular}{|c|c|c|c|c|}
\hline Series & Errors & $\begin{array}{l}\text { Error Not Reported to } \\
\text { the Victim }\end{array}$ & $\begin{array}{l}\text { Error Reported to the Victim, but No } \\
\text { Legal Action Taken }\end{array}$ & $\begin{array}{l}\text { Error Reported to the Victim and Legal Action } \\
\text { Taken Against the Provider }\end{array}$ \\
\hline \multirow{2}{*}{$\begin{array}{l}\text { The } \\
\text { Resident }\end{array}$} & \multirow{2}{*}{41} & 23 & 12 & 6 \\
\hline & & $(56.1 \%)^{\star}$ & $(29.3 \%)$ & (14.6\%) \\
\hline \multirow{2}{*}{$\begin{array}{l}\text { The Good } \\
\text { Doctor }\end{array}$} & \multirow{2}{*}{23} & 8 & 14 & 1 \\
\hline & & (34.8\%) & $(60.9 \%)^{*}$ & $(4.3 \%)$ \\
\hline \multirow{2}{*}{ Code Black } & \multirow{2}{*}{50} & 31 & 19 & 0 \\
\hline & & $(62.0 \%)^{\star}$ & $(38.0 \%)$ & $(0.0 \%)$ \\
\hline \multirow{2}{*}{$\begin{array}{l}\text { Chicago } \\
\text { Med }\end{array}$} & \multirow{2}{*}{31} & 18 & 13 & 0 \\
\hline & & $(58.1 \%)^{\star}$ & (41.9\%) & $(0.0 \%)$ \\
\hline \multirow{2}{*}{$\begin{array}{l}\text { Grey's } \\
\text { Anatomy }\end{array}$} & \multirow{2}{*}{30} & 15 & 15 & 0 \\
\hline & & $(50.0 \%)^{*}$ & $(50.0 \%)$ & $(0.0 \%)$ \\
\hline \multirow{2}{*}{ House } & \multirow{2}{*}{41} & 11 & 30 & 0 \\
\hline & & $(26.8 \%)$ & $(73.2 \%)^{*}$ & $(0.0 \%)$ \\
\hline \multirow{2}{*}{ Scrubs } & \multirow{2}{*}{15} & 8 & 7 & 0 \\
\hline & & $(53.3 \%)^{\star}$ & $(46.7 \%)$ & $(0.0 \%)$ \\
\hline \multirow{2}{*}{ ER } & \multirow{2}{*}{11} & 5 & 4 & 2 \\
\hline & & $(45.5 \%)^{\star}$ & (36.4\%) & (18.2\%) \\
\hline \multirow{2}{*}{ Overall } & \multirow{2}{*}{242} & 119 & 114 & 9 \\
\hline & & $(49.2 \%)^{*}$ & (47.1\%) & (3.7\%) \\
\hline
\end{tabular}

\section{TABLE 9: Reporting of medical errors}

*Denotes more common reporting outcome for each series as well as TV shows overall.

Although there are no studies for direct comparison, prior studies have reported that as many as $85 \%-90 \%$ of medical errors may go unreported each year [16]. Therefore, medical error reporting may occur more often in TV series than real life.

\section{Discussion}

To our knowledge, this is the first study to look at the depiction of medical errors in a sample of medical TV shows, allowing for a comparison between dramatized shows and reality. We were able to examine several medical series over a broad range of years, settings, and genres to get a diverse sample of medically based TV programming. In order to ensure consistency and objectivity, four medical students reviewers were provided pre-defined definitions and categories for all data points. The use of categories previously described in the medical error literature allowed for direct comparisons between TV shows and reality. Following collection and analysis, we have highlighted several discrepancies in the depiction of medical errors compared with statistics from US hospitals that could affect medical consumers in a variety of ways.

The dramatization of medical errors in medical TV series may lead to an unnecessary amount of fear and anxiety in its viewers. As discussed above, TV series depicted medical errors as resulting in mostly emotional trauma or temporary injury. Although most patients experienced only emotional trauma, negativity bias argues that viewers are more likely to remember and have their opinions formed by negative experiences 
than positive [17]. Leveraging this theory, patients are more likely to recall the negative outcomes depicted on TV, thus increasing their anxiety surrounding medical care. Additionally, medical TV series overrepresent certain types of errors such as improper diagnosis and improper therapy while underrepresenting operative error. This could lead to patients experiencing more anxiety during the diagnostic stage, despite there being a lower risk for error [4-5].

The increased fear and anxiety experienced by consumers of medical TV shows may lead to an increased number of medicolegal cases. As discussed above, the most common types of medical errors depicted on TV were improper diagnosis or operative error, resulting in emotional trauma or temporary injury. Viewers of medical TV shows may react to depictions of these types of errors by feeling empowered to advocate for similar errors they experienced. Fitting with this theory, although the most common medical error is an operative error, the most commonly filed medical malpractice claim is an error in diagnosis $[4,5,18]$. However, the poor reporting of medical errors depicted by TV series may lead to excessive anger and revenge that results in an increased number of unnecessary medicolegal cases. For example, although $7.4 \%$ of physicians have a malpractice claim filed against them each year, only $22 \%$ of these claims hold up in a court of law and result in compensation $[18,19]$.

These dramatizations might also affect the patient-physician relationship that can result in poor healthcare utilization and health outcomes. Based on our sample, the most common healthcare provider depicted as responsible for an error was an attending physician. The attending physician should represent the healthcare provider with the most knowledge and expertise, overseeing physicians in training, other specialty physicians, advanced practice clinicians and other staff. By watching medical errors and adverse events occur on TV, viewers may begin to mistrust their attending physician and develop a negative view of the entire healthcare system. Patients with lower levels of physician trust are not only more likely to delay seeking medical care, but also they have higher rates of treatment discordance, poor treatment followthrough and overall worse health outcomes [20-22].

The depiction of medical errors in medical TV shows may also impact the education and training of healthcare providers, as well as the development of hospital policies and procedures to ensure safety. After being exposed to the medical errors depicted on TV, viewers in the medical field may feel inspired to educate themselves and others on the prevention of errors and how to properly communicate with victims of error. For example, many medical schools are creating curricula that educate students on how to recognize medical errors and employ proper methods of error disclosure [23,24]. Some studies have even examined the use of medical TV shows such as House and Grey's Anatomy to introduce the topics of ethics and teamwork [25]. For already practicing physicians, states are starting to require that some hours of continuing education be dedicated to the prevention and disclosure of medical error [26]. At the institutional level, many hospitals have implemented error prevention protocols based on the Swiss cheese model that centers around the types of errors heavily represented in our sample of TV shows [27]. For example, to prevent against operative and procedural errors, hospitals have enacted policies such as pre-procedure site marking, time-outs to confirm identity and procedure prior to incision, and equipment counts. To prevent against errors in diagnosis, hospitals have enacted policies such as simplification of the electronic medical record for the ease of accessing and interpreting results, providing diagnostic checklists or algorithms, and implementing computer programs that integrate patient information to suggest possible diagnoses [28].

This study is not without limitations. Although we selected eight medical TV series representing a broad range of years, settings, and genres, our results may not be generalizable due to exclusion of many other medical TV series. Despite only analyzing a subset of episodes from each series, we chose to include episodes from both the beginning and end of each season allowing for appreciation of the entire plot line. In addition, analyzing a certain number of episodes per season prevented series with more episodes from overshadowing the results of other series for the cumulative results. Second, we recognize that the diversity of races and ages depicted on TV does not always mirror the diversity of our nation and thus may skew the demographic data $[29,30]$. However, it is important to recognize these demographic differences and how they may affect viewer attitudes. Third, there was significant variability among reviewers in their rate of medical error reporting. We attempted to limit the amount of variability by providing standardized definitions and selecting medical students with similar levels of training; however, we acknowledge that each reviewer may have implicit biases that affects his/her interpretation of the depicted events. This variability was accounted for in our statistical models by adjusting for reviewer in each model. Despite this adjustment, the extended Kappa coefficient showed only low-moderate agreement among the four reviewers. We believe that this variability allows for appreciation of the variability that would exist among common viewers. Fourth, our results for the medical error rate are expressed as errors per hour rather than errors per patient admitted, and direct comparisons could not be made in regard to rate. We considered recording error as errors per patient depicted on a show, but felt this would falsely elevate the rate of medical error since not all patients in a TV hospital receive screen time and there is no way to estimate bed capacity of these fictional hospitals. Lastly, this study was only able to describe the frequency of medical error depicted on TV and provide comparisons to US hospital data. Although we have discussed how viewing the depiction of medical errors may affect viewers and healthcare provider attitudes, a correlation between the two was not measured. 


\section{Conclusions}

Based on our sample of medical TV shows, we found discrepancies in the depiction of medical errors compared with statistics from US hospitals. This may lead to excessive fear and anxiety in viewers that results in delays in seeking medical care and increased medicolegal cases. Medical schools and healthcare systems are already instituting methods to prevent medical errors and educate providers on methods of proper error disclosure. Future studies should focus on determining whether exposure to medical TV shows affects the viewer attitudes towards healthcare providers and systems, as well as the outcomes of these attitudes such as delays in care or a higher number of medicolegal cases.

\section{Additional Information}

\section{Disclosures}

Human subjects: All authors have confirmed that this study did not involve human participants or tissue. Animal subjects: All authors have confirmed that this study did not involve animal subjects or tissue. Conflicts of interest: In compliance with the ICMJE uniform disclosure form, all authors declare the following: Payment/services info: All authors have declared that no financial support was received from any organization for the submitted work. Financial relationships: All authors have declared that they have no financial relationships at present or within the previous three years with any organizations that might have an interest in the submitted work. Other relationships: All authors have declared that there are no other relationships or activities that could appear to have influenced the submitted work.

\section{References}

1. Anderson JG, Abrahamson K: Your health care may kill you: medical errors . Stud Health Technol Inform. 2017, 234:13-17. 10.3233/978-1-61499-742-9-13

2. National Association of Insurance Commissioners: Guideline for Implementation of Medical Professional Liability Closed Claim Reporting. (2010). Accessed: October 10, 2020: https://www.naic.org/store/free/GDL1077.pdf.

3. Brennan $\mathrm{T}$, Leape $\mathrm{L}$, Laird $\mathrm{N}$, et al.: Incidence of adverse events and negligence in hospitalized patients: results of the Harvard Medical Practice Study I. N Engl J Med. 1991, 324:370-376. 10.1056/NEJM199102073240604

4. Leape LL, Brennan TA, Laird N, et al.: The nature of adverse events in hospitalized patients: results of the Harvard Medical Practice Study II. N Engl J Med. 1991, 324:377-384. 10.1056/NEJM199102073240605

5. Thomas E, Studdert D, Burstin H, et al.: Incidence and types of adverse events and negligent care in Utah and Colorado. Med Care. 2000, 38:261-271. 10.1097/00005650-200003000-00003

6. O’Neil AC, Petersen LA, Cook EF, Bates DW, Lee TH, Brennan TA: Physician reporting compared with medical record review to identify adverse medical events. Ann Intern Med. 1993, 119:370-376. 10.7326/0003-4819-119-5-199309010-00004

7. Weingart NS, Wilson RM, Gibberd RW, Harrison B: Epidemiology of medical error. BMJ. 2000, 320:774-777. 10.1136/bmj.320.7237.774

8. Andrews L, Stocking C, Krizek T, Gottlieb L, Krizek C, Vargish T, Siegler M: An alternative strategy for studying adverse events in medical care. Lancet. 1997, 349:309-313. 10.1016/S0140-6736(96)08268-2

9. Shanahan J, Morgan M: Television and Its Viewers: Cultivation Theory and Research . Cambridge University Press, New York, NY; 1999. 10.1017/CBO9780511488924

10. Gordon PN, Williamson S, Lawler PG: As seen on TV observational study of cardiopulmonary resuscitation in British television medical dramas. BMJ. 1998, 317:780. 10.1136/bmj.317.7161.780

11. Monahan K, Ducach G, Olympia RP: Cardiopulmonary resuscitation survival rates depicted in emergency department-associated medical television shows. Resuscitation. 2019, 135:236-237. 10.1016/j.resuscitation.2018.12.017

12. Diem SJ, Lantos JD, Tulsky JA: Cardiopulmonary resuscitation on television-miracles and misinformation . N Engl J Med. 1996, 334:1578-1582. 10.1056/NEJM199606133342406

13. Portanova J, Irvine K, Yi JY, Enguidanos S: It isn't like this on TV: revisiting CPR survival rates depicted on popular TV shows. Resuscitation. 2015, 96:148-150. 10.1016/j.resuscitation.2015.08.002

14. Gergenti L, Caiado A, Lacek L, Olympia R: The depiction of major disasters in emergency departmentassociated medical television shows. [Online ahead of print]. Am J Emerg Med. 2020, 10.1016/j.ajem.2020.05.064

15. Jones NA: Update on the US Census Bureau's race and ethnic research for the 2020 census . Survey News. 2017, 3:1-4.

16. Shaw G: Most adverse events at hospitals still go unreported. The Hospitalist. 2012, 7:1.

17. Rozin P, Royzman EB: Negativity bias, negativity dominance, and contagion. Pers and Soc Psychol Rev. 2001, 5:296-320. 10.1207/S15327957PSPR0504_2

18. Schaffer A, Jena A, Seabury S, Singh H, Chalasani V, Kachalia A: Rates and characteristics of paid malpractice claims among US physicians by specialty, 1992-2014. JAMA Intern Med. 2017, 177:710-718. 10.1001/jamainternmed.2017.0311

19. Jena AB, Seabury S, Lakdawalla D, Chandra A: Malpractice risk according to physician specialty . N Engl J Med. 2011, 365:629-636. 10.1056/NEJMsa1012370

20. Trachtenberg F, Dugan E, Hall MA: How patients' trust relates to their involvement in medical care. J Fam Prac. 2005, 54:344-352.

21. Dean LT, Moss SL, McCarthy AM, Armstrong K: Healthcare system distrust, physician trust, and patient discordance with adjuvant breast cancer treatment recommendations. Cancer Epidemiol Biomarkers Prev. 2017, 26:1745-1752. 10.1158/1055-9965.EPI-17-0479 


\section{Cureus}

22. Lee YY, Lin JL: How much does trust really matter? A study of the longitudinal effects of trust and decisionmaking preferences on diabetic patient outcomes. Patient Educ Couns. 2011, 85:406-412. 10.1016/j.pec.2010.12.005

23. Halbach JL, Sullivan LL: Teaching medical students about medical errors and patient safety: evaluation of a required curriculum. Acad Med. 2005, 80:600-606. 10.1097/00001888-200506000-00016

24. Gunderson AJ, Smith KM, Mayer DB, McDonald T, Centomani N: Teaching medical students the art of medical error full disclosure: evaluation of a new curriculum. Teach Learn Med. 2009, 21:229-232. 10.1080/10401330903018526

25. Hirt C, Wong K, Erichsen S, White JS: Medical dramas on television: a brief guide for educators . Med Teach. 2013, 35:237-242. 10.3109/0142159X.2012.737960

26. State CME licensure requirements . Accessed: October 10, 2020: https://www.cecentral.com/licensure/cme/.

27. Perneger TV: The Swiss cheese model of safety incidents: are there holes in the metaphor? . BMC Health Serv Res. 2005, 5:71. 10.1186/1472-6963-5-71

28. Pham J, Aswani M, Rosen M, Lee H, Huddle M, Weeks K, Pronovost PJ: Reducing medical errors and adverse events. Annu Rev Med. 2012, 63:447-463. 10.1146/annurev-med-061410-121352

29. Healey T, Ross K: Growing old invisibly: older viewers talk television. Media Cult Soc. 2002, 24:105-120. 10.1177/016344370202400107

30. Mastro DE, Greenberg BS: The portrayal of racial minorities on prime time television . J Broadcast Electron Media. 2000, 44:690-703. 10.1207/s15506878jobem4404_10 